\title{
GCU
}

Glasgow Caledonian

University

University for the Common Good

\section{Directions, disconnect and critique: round table discussion}

Lennon, J. John; Seaton, Tony V.; Wight, Craig

Published in:

Worldwide Hospitality and Tourism Themes

DOI:

10.1108/WHATT-12-2016-0074

Publication date:

2017

Document Version

Author accepted manuscript

Link to publication in ResearchOnline

Citation for published version (Harvard):

Lennon, JJ, Seaton, TV \& Wight, C 2017, 'Directions, disconnect and critique: round table discussion',

Worldwide Hospitality and Tourism Themes, vol. 9, no. 2, pp. 228-239. https://doi.org/10.1108/WHATT-12-20160074

\section{General rights}

Copyright and moral rights for the publications made accessible in the public portal are retained by the authors and/or other copyright owners and it is a condition of accessing publications that users recognise and abide by the legal requirements associated with these rights.

Take down policy

If you believe that this document breaches copyright please view our takedown policy at https://edshare.gcu.ac.uk/id/eprint/5179 for details of how to contact us. 


\title{
Directions, disconnect and critique: Round table discussion
}

J John Lennon, Director of Moffat Centre for Travel and Tourism, Glasgow Caledonian University, UK

'Tony' A V Seaton, Professor of Tourism Behaviour, University of Limerick, Ireland Craig Wight, Lecturer in Tourism and Hospitality Management, Plymouth University, UK

\begin{abstract}
Purpose: Reviews developments in dark tourism research over a 20 year period from its inception in 1996. Considers the reasons why people visit dark tourism sites and the different perspectives of site operators, tourists and academics.

Design/methodology/approach: Uses a round table discussion with three participants - all researchers who played a significant role in developing the early concept of dark tourism. Explores a number of questions about past, current and future research interests and developments.
\end{abstract}

Findings: Observes that dark tourism site operators and visitors tend to view the act of remembrance as a significant reason for visiting a site associated with past atrocities. This perspective is rather different from the original concept of dark tourism - viewed by many as a form of pilgrimage tourism.

Practical implications: The review reveals a gap between aspects of the literature on dark tourism and the reasons why these sites remain popular with tourists. Site operators and visitors say that motives for visiting are more commonly associated with an act of remembrance and a sense of pilgrimage than a desire to view a site associated with pain and death.

Originality/value: This viewpoint provides a 20 year perspective on research in dark tourism based on a conversation between three of the most eminent researchers in the field.

Keywords: Dark tourism, Research, Museums, Attractions

Professor J John Lennon, Professor Tony Seaton and Dr Craig Wright were early researchers in the field of Dark Tourism. A selected bibliography of some of their work is included at the end of the discussion as well as specific sources referred to in the discussion.

John: As early researchers in the field, what currently interests you in the area of Dark Tourism?

Tony: Well, over the last year I've had a really big change of mind about it, which is very simply that- in the past, it's been defined as tourism associated with death and what we've been trying to look for is people who might be interested in that and who might, in marketing terms constitute a marketing segment. I now think that this way of defining Dark Tourism was wrong. I see Dark Tourism as encounters with different kinds of remembrance of mortality and fatality which means that it is representation of death, rather than death itself that is the issue. So basically, I'm less interested in the concept of the dark tourist as a distinct species because I think that we're all dark 
tourists on occasion, and the more interesting question is what are the encounters we have with representations of remembrance, and to what extent have they been accidental, premeditated or incidental. I'm interested in the power behind remembrance and commemoration more than trying to identify a dark tourist and looking at motivation.

John: Craig, same sort of question. Where do you think Dark Tourism is moving and what interests you in the field currently?

Craig: I think I've been most interested in the research dynamic that goes into these areas. If you look at the journals and the research that comes out and typically it is involved with identifying new motivations and interpretations. It's all kind of sociological stuff; surveys, questionnaires, interviews and that kind of research. At the same time while I'm interested in it, I'm also interested in the humanities outlook and specifically looking at discourse as a research method. I am more interested in approaching heritage sites and museums as 'texts'; as defined by some of the post-structuralist theory. You can look then at interpretation without really having to interview anyone or do any surveys, you're simply interrogating narrative and you're giving a critical reading of that. You're questioning who is writing this on whose behalf. Who are the missing subject positions within these versions of history. I kind of took that idea and looked at Lithuania, which you (J John Lennon) put me onto because you had observed this absence of a narrative of the Lithuanian Holocaust. It simply just was not there. How can you have a museum of genocide victims in the heart of Lithuania and not actually mention the holocaust? So I interrogated areas like; visitor tours, written and spoken narratives, books, leaflets and the web. I then looked at all that stuff that had been written around genocide in Lithuania and found preferred versions of how history is told in these spaces. Thus I am approaching it from an angle which challenges the methods they had used to date to interrogate these things. I'm more interested in museums as units of analysis in research as far as dark tourism research is concerned. The most important stuff, the kind of Dark Tourism 1.0 stuff, which came out in late 1990 s was the most important.

Tony: I feel if you must take out the notion of the pre-motivated tourist, which is hard to sustain because what you actually find is, that most people visiting dark tourism sites, deny the fact that they're dark tourists; they don't actually see themselves as afficionados of transgressive behaviour suggested by the word "dark".

Craig: Do the site managers/ curators see the sites as dark tourism locations ?

Tony: They don't. Rejection of the "dark" label is even stronger when you actually look at these sites. Three instances of this have particularly struck me in recent years. One was talking to the Toni and Valma Holts who run Holts Battlefield tours. They fiercely resist being called dark tourism providers and they say there's nothing dark about the what they see more as pilgrimages than tourism. They believe they and their touring groups are paying homage and allowing people to remember the fallen in a very honourable way'. Two years ago I interviewed the Director of the Association of Significant Cemeteries in Europe and she also denied that there is anything dark about her organisation. She talked about how at cemeteries in Slovenia they were trying to extend visits by school children using them as teaching resources in history and environmental studies. Very recently I examined a $\mathrm{PhD}$ for the University of Central Lancashire where the student had done her study on Rwanda and the aftermath of the civil war. There they were exhibiting a lot of the physical evidence of atrocities in their museums, including skulls and relics; but they again deny that there 
is anything dark about this. They see the exhibits as a way of bringing both sides together after the war and genocide ended to make them aware of the havoc that they had caused. So... if you have a visitor who says "I am not a dark tourist" and you have suppliers who say "darkness is not what we are about" where does that leave "dark tourism"? However, if you regard the sites as sites of the remembrance of death, then it's a different playing field... Remembrance can be of many different kinds...

Craig: Is there a sort of pejorative connotation around the term dark tourism then? I think there is and that's why sites are less enthusiastic about the concept.

John: I think it's amusing that if the sites don't want to be known as dark sites, and tourist don't want to be known as dark tourists the only people who are talking about dark tourism are academics! However, I do think what you're doing is a more sophisticated analysis of what is going on and I think what we did way back in 1996 was identify territory; we planted a flag in the ground. We said there is a phenomena here which merits scrutiny. I think what you're hinting at is what I categorize as écoute et répète, where we look at dark tourism sites or instances in; Canada, Britain, Australia, Germany; it becomes an endless list. The other thing which seems to circulate are obsessive definitional debates, spectrums and typologies. This is of course typical of the way some academics get caught up in the detail and miss the big picture material.

So, whose work are you reading now? Are you reading outside of the area or looking at history more broadly, undertaking more traditional historical research with documentation and primary sources or is your work moving towards theorists who have not thus far been cited?

Craig: I suppose I did a classical dark tourism lit review for my $\mathrm{PhD}$ - it drew in the usual, as I put it - 'generation one' theorists. I did not go near the dark spectrums but I went into debates around method and methodology. I proposed that nobody has used some of these critical theorists as yet and researchers had not embraced post-structuralist research to have a look at dark tourism. I brought in this idea of Foucault and his concept of the archaeology of knowledge (Wight, 2014). Also, the rules of how things are represented and either included or excluded within museums. I think he said that "All that could be said is never said", (Foucault, 2002) that there's a certain preferred narrative that's projected through visitor interpretation. It was a critical reading of that kind of subject position; how objects of knowledge become created by certain narratives that interests me.

For example, there are an awful lot of reminders of the dominant narrative of Lithuanian ethnic genocide in Lithuanian genocide museums. If you go to the national Genocide museum, you'll see some reference to Holocaust; it is not 'invisible'. However, they would appear to prefer to portray ethnic Lithuanian genocide through the aesthetic of gore and violence. As a consequence you come across these images of slain partisans; when the interpretation focuses on ethic Lithuanian tragedy. But you do not see that with holocaust interpretation which is more sanitised and less visible. There is no violence and there are no victims in the museum environment. They don't use imagery to tell the story, they tell it in a more contemporary /modern day context in a way that foregrounds reconciliation and fundamentally backgrounds the inconvenience of Nazi collaboration. This suggests that the text is just as important as the consumer and the producer is at the crux of my personal exploration of the field.

Tony: I'm more interested in the history and the way history is used in the present. If you take the focal point of dark tourism to be remembrance, rather than death, then a 
whole range of questions emerge that have previously been invisible. Who chooses to commemorate some events and people not others? How is it done? Who provides the resources and finance? How soon does it start after the death of those commemorated? How long does it last? And when does the production of memorials stop? These are questions that have been hardly been considered in dark tourism discourse. They are salient, for instance, in the case of holocaust commemorations which, apart from roadside memorials, are the most rapidly expanding area of memorials in modern times; and not just in monumental commemorations, but in the continual plethora of new books, articles, programmes and research studies. How does it come about that 70 years after the events happened and most of the victims and perpetrators are dead, that mechanisms of remembrance have rather increased than slowed down, leading some commentators, notably Finkelstein, to speak of a "Holocaust Industry" that is more about the politics of today, than the genocidal suffering of Jews, gypsies and homosexuals who died in the death camps (Finkelstein 2000). For Finkelstein keeping the Holocaust at the forefront of international, public agendas, has been pursued over several decades as kind of firewall against criticism of the Israeli state for its occupation and activities in Palestine.

The other side of the coin to seeing the "engineering and orchestration of remembrance" (Seaton 2016 and 2017) for specific reasons, as the hallmark of much dark tourism, is the absence of remembrance of other contemporary issues relating to death and fatality, The French sociologist introduced the phrase "significance silences" as an analytical term in the study of cultural narratives; what, in dark tourism, could be called "curious cases of memorials that never get erected". In the USA, the huge incidence of gun homicides might be an agenda for some national monument and perhaps a day of remembrance, in educating people into less programmatic support for carrying weapons. The world might also be made a better by engineering annual remembrance of people who die in police custody across the world, as a way of drawing attention to comparative levels of police brutality, with league tables pressurising the more repressive to be reined in.

John: Acceptable and unacceptable histories, selective interpretation - it has been given a couple of names. I mean, I'm always intrigued that when I go to Germany I witness an openness in their museums and exhibits about the rise of fascism and the perpetration of the holocaust. There is a clear focus on documentation rather than entertainment or exploitation. In Germany the past is everywhere. You go to Berlin and it's a city that's like an onion, uncovering itself layer by layer; first Reich, the third Reich etc. Furthermore they take pains to debate the conservation issues in respect of ruins like the Zeppelin field in Nuremberg. Do we let it crumble, do we commemorate it? These debates that Philpot (2016) covers in his writing.

Craig: I'm interested in the iconography of the holocaust. Tim Cole wrote a book called 'Packaging the Holocaust' (Cole, 1999) and he remarked upon the various cultural icons across the world, and how they're quite fluidly used in culture. Anne Frank was one that he chose to focus on that is appropriate in this context. He argued she has been packaged and sold to the Americans and they have a version of Anne Frank that is kind of stripped of some of her history. They've produced plays and television series of Anne Frank and she's stripped of her sexuality and her story is abridged. As in her diary, if you read it in full there is an awful lot about a young girl growing up so its these 'selective silences' (Wight and Lennon, 2007) again in terms of the icons of holocaust. 
Tony: One other area which I'm interested in which is slightly separate from what we've been talking about is in seeing dark tourism as a disciplinary part of the broader study of thanatology which is a growing interest in universities - e.g. Bath University and York. You can look upon dark tourism as a travel dimension in which the lay tourist becomes an amateur student of culture while abroad. The customs and symbolism attached to death were always principal concerns for field workers studying other cultures during the heyday of anthropology between about 1870 and the 1980 .

John: I've always contested that media and now, social and digital media channels have an important role in this. Currently we're uploading literally millions of images daily to Facebook, Instagram, Flickr and much of that content which ends up on peoples' Facebook pages will juxtapose holidays and good times and selfies with pictures of Auschwitz and dark sites visited. I wonder if you've got any thoughts on the way these visual elements are now being uploaded and shared along with the banality of other aspects of people's lives?

Craig: I think it represents an opportunity doesn't it. I mean there's definitely something there for discourse analysis and there's people constructing ideas about these sites all the time on social media.

John: The technologists talk about data mining and where I've seen it done is in travel where they look at Facebook sites and an awful lot of Facebook is people on their holidays. Herein we find dark sites represented, recorded, photographed and uploaded.

Craig: I said before that's it's a form of cultural capital like any other and something you collect.

Tony: Craig, your writing is a very good example of analysing that and it fits partly with my feelings about the various forms remembrance may take. If you took the concept that dark tourism is about contact with death and you looked at say Grutas Park in Lithuania you might conclude that it had the same meaning for everyone. However, it's not the case; what is remembered differs for different audiences, even though the physical appearance of the statues of fallen Cold War leaders is the same for all.

Tony: Going back to the impact of social networking and the circulation of images they generate... Despite their volume the first thing that you feel when you look at many of them is that they represent continual re-duplication of the same images. It is like looking at people's holiday albums, that conform to stereotypical, photographic conventions in which pictures are mainly taken from the front, with everyone smiling and very often the iconic sight they want to be associated with located just behind them. This is common in much travel photography and it means that despite the huge circulation of imagery, you're actually getting the same discourse being recycled and reproduced as induced, eternal recurrence. This photographic cloning is one of the key factors that makes tourism increasingly, what I have called metempsychosis and metensomatosis (Seaton 2013); in crude terms, repetition of conventional patterns of travel and experience in the footsteps of others, which are now massively reinforced by international social network pass-ons.

The other factor affecting social networking is the promotional interventions by large organisations into shaping personal travel agendas. The Australian Tourist Authority have been very successful in producing and transmitting destination images, that then stimulate and generate other photographic contributions on the social networks. So the images you see circulating are partly a result of the like/dislike pass-on factor, but 
also due to corporate interventions by organisations shaping the agendas of social networking to their own ends. You don't get the spontaneous diversity of images you might expect when looking at millions of images uploaded by many thousands of people of place and events, due partly to the subtle shaping and engineering of tourist happenings by digital marketing agencies. Part of our Tourism MA in Ireland seeks to get students to think about alternative and different ways of experiencing place and space in tourism, by looking at psychogeography and experimental travel that attempt get away from the dominant conventions of visiting and photographing (Rough Guide . Students have produced some interesting videos, shot with smart phones, that feature unusual and unexpected imaging including dark tourism content

Craig: Situationists then?

Tony: Exactly yes.. Guy Debord's "Society of the Spectacle" is one of the situationist texts that forms part of the psychogeographical materials the students get to hear about (Debord 1967) The new tourist !! The new tourism!!!

Craig: It's just another victory for social constructivist approaches; how people DIY their own experiences and the image can be quite telling about that. I believe it was well demonstrated at Grutas Park, Lithuania. There is clearly a research opportunity for "crowd sourcing dark tourism experiences" or something like this.

Tony: Do you think that some cultures are much more predisposed to dark tourism than others?

Craig: This is the concept of material repeatability, which is Foucault's terminology (Foucault, 2002) and it's the idea that as soon as you see a certain narrative appearing a certain number of times in different settings of dark tourism, in a national setting, you can start to understand what's dominant and start to consider maybe who's missing from this piece. We are then looking for certain rules about the way that things are spoken about and those give clues as to what's been privileged and what's been sequestered or not spoken about.

Tony: I can understand that people might remember particular aspects of history that they or their parents or grandparents were involved in more than others. But do you not think that in dark tourism, it's something more than that.. something about national and cultural differences? ? For example, I think the English, the Germans and the French, have a more "Gothic imagination" than many people from other countries, because they had the Romantic movement, and have always been more interested in reflections and dreams and reveries and 'romantification' of the past. The visiting of the graves of European authors became big in the early $19^{\text {th }}$ century, but you don't find it, I think, so much in Italy and probably hardly ever in many other parts of the world. It's part of the fact that the Gothic grew up in a few nations in Western Europe, and that has had a long term effect on what we now call dark tourism internationally.

Craig: A history of literacy is perhaps important..

John: With literacy goes memory.

John: Okay, a quick one then. Factors such as authenticity and experience are probably overused in respect of this.

Craig: The best way I have heard this explained is with the term authenticity being described as being a return on your investment of time as a visitor consuming culture. Thus 
authenticity is extremely personal and what's authentic to me may not be to you and therefore its highly subjective and socially constructed. The second thing is that it's a slippery concept that doesn't really have a fixed meaning. It probably has a fixed meaning in an art gallery but when it comes to the visitor experience I think it's highly individualised.

Tony: It would be useful, when talking about authenticity to distinguish whether you're using authenticity to talk about the subjective experience, or the object which is the subject of the experience ; because they are two different things. On one hand you might look, for example at a kitsch plastic statue of the Virgin Mary but you might still have an authentic experience because of the feelings it provokes in you. Others might say that it is cheap kitsch image... not authentic... a fake whereas the experience could in fact be existentially valid. Conversely some gigantic Biblical painting by Rubens, authenticated as a masterpiece by the gurus of the art world, might leave some viewers cold.

John: I want to get you closer to simulation now and embodiment, the kind of stuff that Merlin Entertainment's Dungeon Experience and prison re-enactment offers. Is this a concern about how history is being utilised ? How our heritage is being treated ? Or is that simply acceptable and part of the way the industry has embraced this stuff?

Tony: I see it as just one of the different forms of remembrance that you can have. I mean, if you think for example, about the dark tourism links between dining in a Vampire Restaurant in New York, going to a dungeon experience, and going to a famous person's grave side. All of them, in their own way, are instances of remembrance but the kind and quality are different is different. Vampire restaurants are examples of parodic or jokey forms of remembrance, like ghost trains and haunted houses at fun , where you play at being frightened or you play at believing in ghosts. This is why I make remembrance the subject, because what you're always looking at is the nature of remembrance of either mortality or fatality and in a sense it bypasses reality. A dungeon experience may be less parodic and have more "authentic" substance in the historical narratives told. And the graveside visit is the most "serious and authentic" But none of it has to be authentic in the same terms; all that really matters is what kind of remembrance you are bringing to it and how that has been shaped before and during the encounter.

Craig: Remembrance is in the eye of the beholder so if it doesn't fit your ideals or assumptions of what it should be then it's inauthentic. It's down to individuals I think.

John: I like the idea of remembrance. Where I struggle with it is in certain site. For example, a Khmer Rouge site, which is basically where a traveller might get a trigger about a period they never heard of. The sites and the limited narrative they offer might (or might not) I suppose act as a catalyst for discovering more. It's not remembrance, its education almost by omission.

Tony: But it is remembrance... If you take the definition I'm using, that dark tourism is a encounters with engineered and orchestrated remembrance of fatality. The education takes place through the processes of remembrance induced at the site.

John: I don't think it's been engineered as such, it's a kind of legacy that the government can't quite bring themselves to get rid of because it's become so notorious. The thing that worries me is that their practice and policies (in the case of certain countries) is about obliterating the past. In the case of Khmer Rouge prisons, they used to litter the 
country but now there's maybe half a dozen left and only one, really developed as a tourist / education offer. It would seem the government of Cambodia is deeply uncomfortable with its past.

Tony: So are you saying it's only a token exhibition compared to what it could be? That would be a good example of what you mentioned earlier of selectively induced remembrance. Engineered remembrance involving editing and exclusions and suppression.

John: The difficulty for them now of course is the internet and the visibility of all this material and the fact that if you are interested and put Khmer Rouge into a search engine, you will get a lot of detail, documentation, evidence, witness statements etc.

Tony: I think I missed a major issue in the past, the fact that thanatourism is interdiscursive, By which I mean that remembrance may be engineered in many different forms and media at the same time, and through time. The digital world is the latest and the probably the most instantly pervasive.. Interdiscursive factors are obvious when you go round Elvis Presley's Graceland shrine, you're not just reacting to it as a discrete memorial; you're bringing to it many kinds of representation of Elvis Presley that you've had throughout your life; remembrance in the dark tourism experience is often not just a discrete effect of the now, but a discursive bricollage of ideas about the subject gained from other media and representational forms. In the same way, John that in first dark tourism journal you edited (Lennon 1996), you wrote about Kennedy memorials as part of a generic group made up of different sites... the Kennedy Library, Arlington Cemetery, the Book Depository from which he was shot etc. etc.. As well as a huge weight of other kinds of representation.... So you can't actually look at a single site in isolation, unless it's a private family grave, because of course the simplest form of commemorations are the monuments built to parents, wives and children, which are relatively untouched by wider discourses.

Craig: In a journal article on Schindlers List the film (Grant, 2006), it was recorded that there's a spot in Krakow which is near the factory where the only scene that's shot in colour is the little girl who runs away from the crowd and is shot dead. The author noted crocodiles of tourists were queuing up to cry there where she fell, and it is pure fiction. So that's pure mediated discourse which people had brought to that setting.

John: That brings us nicely to the Schindler factory along with the house that Hitler was born in, located in Austria. I'm interested in your views whether or not such heritage is preserved or we allow it to crumble. There's a famous German historian of the third Reich called Norbert Fry who believes unequivocally that we should let these things crumble, that it's a bad use of resources, rebuilding, conserving sites. For example, in the case of the Zeppelin field, Nuremberg, it is a massive structure that's slowly crumbling.

Craig: I suppose it starts with who is funding it? Who is bringing it to life as an attraction, who is behind it? When I looked at Lithuania I found that the Genocide had been brought to life as a product in tourism by Government. The Jewish community had no funding to do this so they produced their smaller museum where volunteers run it and it is voluntary funded.

John: We're back to Althusser for me and dominant ideological state apparatus; the church, government, the people in power, the elite, etc. I mean, we're dangerously close to conspiratorial thinking. 
John: The last question is where are you going next with your own future research?

Craig: I certainly have one more thing to do in terms of offering a methodological legacy, something that can be applied in different contexts and I'm actually running with that methodological position rather than solely dark tourism.

Tony: I'm interested in separating fatality and mortality in commemoration and remembrance and trying to investigate dark tourism encounters in a more multidimensional way that goes further than looking mainly at visitor motivation and satisfactions...Taking into account not just factors relating to the visitor, but the nature of the memorial, perceptions of the powers behind its genesis, location and design.. So instead of just asking the visitor why they visited using a checklist of options, it might involve other questions like, for example; 'Did you arrive here accidentally, incidentally, or did you pre-plan your visit'. "What do you think of the site and its relationship to its surroundings?" "How does it affect you?". The aim... to get a situationally based, idea about the relationship between the visitor , the site and the commemorated dead.. John noted that there is a tendency to get into endless theories and site case studies. The aim should be to produce a fuller, more situational description of encounters of people at specific sites...What I'm looking for is a more holistic methodology that would provide a number of these things, including the power relations between the viewer and the viewed and their relationship to the remembered dead.

John: I'm mostly motivated by still putting a stick into the bee hive and annoying the bees and in this case it will certainly be the fascist period. In any country where there's a healthy culture of support for fascism I think it merits exploration and investigation.

Tony: I think you've had a very principled and focused direction since you started because I would say that you're terrifically interested in atrocity tourism and of course, history.

\section{References}

Antony, Rachel and Joel Henry (n.d.): "The Lonely Planet Guide to Experimental Travel", Lonely Planet Publications, Melbourne and London.

Cole, T. (1999) 'Images of the Holocaust: The Myth of the Shoah Business', Gerald Duckworth and Co. Ltd: London

Debord, Guy (1967, Trans. 2010): "The Society of the Spectacle", Black and Red, Detroit.

Finkelstein, Norman G. (200o); 'The Holocaust Industry. Reflections on the Exploitation of Jewish Suffering', Verso, London.

Grant, L. (2006) 'Manufacturing History', New Statesman, Arts and Culture, 14th August.

Wight A C (2014) 'Tracking discourses of occupation and genocide in Lithuanian museums and sites of memory' $\mathrm{PhD}$ available here

http://ethos.bl.uk/OrderDetails.do?uin=uk.bl.ethos.618583

\section{Bibliography J John Lennon}

Lennon J J (2016) Dark Tourism Visualisation: some reflections on the role of photography in Stone P (Ed) Handbook of Dark Tourism Studies (forthcoming), Palgrave Macmillan 
Lennon J J (2016) Dark Tourism and Architecture of the National Socialist Period in Germany in Aumann P (Ed) Architecture of the National Socialist Period in Germany (1933-45), Peenemunde Press, Germany

Lennon J J (2010) Dark Tourism and Sites of Crime in Botterill D and Jones T (Eds) (2010) Tourism and Crime, Goodfellow Publishers, Oxford

Lennon J J (2009) Tragedy and Heritage in Peril : The Case of Cambodia in Tourism Recreational Research (Vol 3 No 2 pp 116-123)

Lennon, J.J. (2001) 'Interpretation of the unimaginable: the US Holocaust Memorial Museum, Washington DC, USA and 'Dark Tourism' in French, R.(Ed) (2001) Challenged Tourism, Girne American University, Cyprus .

Lennon JJ with Hooper G (2016) Dark Tourism : Practice and Interpretation, Routledge

Lennon J J Weber D (2016) The Long Shadow: Marketing Dachau, in Lennon J J and Hooper G (2016) Dark Tourism : Practice and Interpretation, pp 26-39Routledge

Lennon J J Wei D Litteljohn D (2012) Dark Tourism: The case of the memorial to the victims of Nanjing (Nanking) Massacre, China in White 1 and Frew E (2012) Dark Tourism and Place Identity: Marketing, Managing and interpreting dark places, Routledge, Oxford.

Lennon J J and Mitchell M (2007) Dark Tourism the Role of Sites of Death in Tourism in Mitchell M (Editor) (2007) Remember Me Constructing Immortality - Beliefs on Immortality, Life and Death, Routledge

Lennon J, and Smith H (2004) A Tale of Two Camps: Contrasting Approaches to Interpretation and Commemoration in the Sites at Terezin and Lety, Czech Republic in Tourism Recreation Research Vol.29 No.1 pp 15-25

Lennon J J and Smith H (2004) Shades of Dark: Interpretation at Terezin, Lety and Czech Republic in Stock A and Kuhle C (2004) Representing the Unimaginable Narratives of Disaster, University of Munster Press, Germany.

Lennon J and Foley M (2003) The Spectacularization of Dark Tourism: Photojournalism, Deontology and Commemoration in the Visitation of Sites of Mass Disaster in Lavoie V (2003) Now: Images of the Present Time, Le Mois de la Photo a Montreal ( $8^{\text {th }}$ edition).

Lennon, J.J. and Foley, M. (2000) Dark Tourism - the Attraction of Death and Disaster, Continuum. (now in $4^{\text {th }}$ International Edition)

Lennon, J.J. and Foley M (1996) 'JFK and Dark Tourism: A Fascination with Assassination' in the International Journal of Heritage Studies Vol. 2, No 1 (pp 198-211)

Lennon, J.J.and Foley M (1996) 'Editorial: Heart of Darkness' in the International Journal of Heritage Studies Vol. 2,No 1 (pp 195-197)

\section{Bibliography Tony Seaton}

Seaton, Tony and Sophie Oorsterwijk (2016): "The British Dance of Death: A memento mori for Jane Austen's era", in, ed. Alessandro Benucci, Marie-Dominique Leclerc and Robert Alain, 
Mort Suit L'Homme Pas a Pas. Représentations iconographiques, variations littéraires, diffusion des thèmes, Actes du Congrès international Danses macabres d'Europe, Troyes, 25-28 mai, Université de Reims Champagne-Ardenne, pp. 302-320.

Seaton, Tony (2016) "Patrimony, engineered remembrance and ancestral vampires: Appraising thanatouristic resources in Ireland and Sicily” ,in, Glenn Hooper and John Lennon, eds., Dark Tourism: Practice and Interpretation, Ashgate, Aldershot..

Seaton Tony (2016): " Encountering engineered and orchestrated remembrance: a situational model of dark tourism and its history", in, ed. Philip Stone, Handbook of Dark Tourism, In Press.

Seaton, Tony and G.S. Dann (2016): "Crime, Punishment and Dark Tourism: The Carnivalseque Spectacles of the English Judicial System" ", in, ed. Philip Stone, Handbook of Dark Tourism, In Press.

Seaton A V (2015) "Last resting places - or recreational spaces? The international evolution of cemeteries as leisure and Thanatourism resources", in, ed. Sam Elkington and Sean Gammon, Landscapes in Leisure: Space, Place and Identities, pp. 71-95, Palgrave, London.

Seaton A V (2014) : "The Unknown Mother: "Thanatourism and Metempsychotic remembrance and rituals after World War 1", in, ed. Liliana Sikorska, Of what is past, or passing, or to come. Travelling in Time and Space in Literature in English, Peter Lang, Frankfurt am Main.

Seaton A V (2013): "Cultivated Pursuits: Cultural tourism as Metempsychosis and Metensomatosis" in, ed, Melanie Smith and Greg Richards, Routledge Handbook of Cultural Tourism, pp. 19-27, Routledge, London and New York.

Seaton A V (2010): "Purposeful otherness :approaches to the management of Thanatourism", in, ed. Sharpley R. and P. Stone, The darker side of travel. The theory and practice of Dark Tourism, pp. 75-108, Channel View Publications.

Seaton A V (2009): “ Beckford and the Tourists: Gothic performances at Lansdown Tower, Bath”, The Beckford Journal, Vol 15,pp. 61-82, Spring.

Seaton, Tony (2009): :Thanatourism and its discontents: An appraisal of a decades's work with some future issues and directions", in, ed. Tazim Jamal and Mike Robinson, The Sage Handbook of Tourism Studies, pp. 521-54, Sage, London.

Seaton, A. V. and J. Lennon (2004): "Moral Panics, Ulterior Motives and Alterior Desires: Thanatourism in the Early $21^{\text {st }}$ Century", in T. V. Singh (ed.), New Horizons in Tourism: Strange Experiences and Stranger Practices, pp. 63-83. CAB International, Wallingford.

\section{Bibliography. C Wight}

Wight, A, C., 2016. Genocide museums as discursive formation. Annals of Tourism Research. Vol. 59. pp. 6o-78 
Wight, A, C., 2013. Myth, rhetoric and human tragedy in Lithuanian museums and sites of memory. Acta Turistica. Vol. 25 (2) pp. 191-210

Wight, A, C., 2009. Competing National Narratives: An Ethical Dimension. In: R. Sharpley and P. Stone (Eds). The Darker Side of Travel: The Theory and Practice of Dark Tourism. Bristol: Channel View Publications. Pp. 129-144

Wight A, C., and Lennon J, J., 2007. Selective Interpretation and Eclectic Human Heritage in Lithuania. Tourism Management. Vol. 28 (2) Pp. 519-529

Wight, A, C., 2007. The Legerdemain in the Rhetoric of Battlefield Museums: Historical Pluralism and Cryptic Parti Pris. In: C.Ryan (Ed). Battlefield Tourism. Elsevier Pp. 111-121

Wight, A. C., 2006. Philosophical and Methodological Praxes in Dark Tourism: Controversy, Contention and the Evolving Paradigm. Journal of Vacation Marketing. Vol. 12 (2) pp. 119-129

Wight, A, C., 2006. Selective Heritage Interpretation in Lithuania. Interpreting World Heritage. San Juan, Puerto Rico. May 1-5

Wight A, C., and Lennon J, J., 2004. Towards an Understanding of Visitor Perceptions of 'Dark' Attractions: The Case of the Imperial War Museum of the North Manchester. Tourism and Hospitality Management. pp. 105-12. 